\title{
EDGE OF CONSTITUENT EFFECTS IN POLISH*
}

\begin{abstract}
Abundant violations of the Sonority Sequencing Generalization in Polish are studied from the perspective of prosodic phonology. We argue that word-initial and nonword-initial extrasyllabic consonants play distinct roles in the operation of phonological rules. We further claim that they are integrated prosodically by linking to the phonological word node and that this is done at different stages of derivation. Transparency of extrasyllabic consonants is also investigated.
\end{abstract}

This article investigates the role that extrasyllabic consonants play in the phonology of Polish. More specifically, we look at those consonants that remain extrasyllabic throughout the whole derivation. Such consonants are typically found at the edges of constituents, in particular, word-initially and word-finally. They are less common at edges of word-medial syllables, unless these syllables appear at the edges of prefixes and stems. The prefixstem juncture abounds in extrasyllabic consonants. As we point out in section 6 , there is a systematic reason why this juncture should have a special place in the phonology of Polish.

The investigation of extrasyllabic consonants leads to two significant observations from the point of view of phonological theory:

(i) Extrasyllabic consonants are transparent, or rather invisible to prosodically conditioned rules of segmental phonology such as assimilation. In the current literature the transparency of consonants has been associated with the fact that nondistinctive features are unspecified (Kiparsky 1985, Steriade 1987). Although our analysis does not contradict this finding, it demonstrates that in the case of the Polish Voice Assimilation underspecification is not a sufficient theoretical tool. The relevant mechanism is the adjacency established at the level of prosodic constituency.

(ii) There is an asymmetry between word-initial and non-word-initial

* This article was written as part of research programme Lett 88/9, Vrije Universiteit, Amsterdam. Jerzy Rubach would like to express his gratitude to the Netherlands Organization for Scientific Research NWO for a grant that enabled him to spend a period of two months in the Department of General Linguistics, Vrije Universiteit. Amsterdam where the research for this article was conducted.

We are indebted to Michael Kenstowicz for his enlightening criticism and valuable suggestions as to the organization of this article. We are also grateful to the three anonymous reviewers for their comments that have led to the improvement of both the content and the form of this study. 
extrasyllabic consonants. This asymmetry comes to light in the analysis of Voice Assimilation and Degemination in Polish. It is also supported by the distribution of syllabic liquids in Czech. Assuming with Itô (1986) that consonants that are not stray-erased must be prosodically licensed, we propose two adjunction rules: Initial Adjunction and Housekeeping Adjunction. In section 6 we investigate the operation of Initial Adjunction and conclude that it must take place in the postcyclic lexical component. It is thus different from Housekeeping Adjunction, which does not take effect until the late stages of postlexical phonology. The two adjunction rules formally express the asymmetry we discover in the analysis of Voice Assimilation and Degemination.

The article is organized as follows. In section 1 we present the basic syllable structure of Polish. We show that in spite of superficial counterevidence Polish obeys the Sonority Sequencing Generalization. This is demonstrated on the one hand by native speaker judgments of permissible syllabification and on the other hand by the role that unsyllabified consonants play in allomorphy rules. The assumption that the Sonority Sequencing Generalization operates in Polish poses the question of what to say about sonorants trapped between obstruents, for instance, the $n$ in the word piosnka 'song'. In section 2 we consider Final Devoicing and conclude that unsyllabified consonants should not be adjoined until later stages of postlexical derivation. Section 3, which looks at Voice Assimilation, uncovers the asymmetry between the word-initial and the non-word-initial unsyllabified segments. The claim that they are asymmetric is strengthened by the operation of Degemination (section 4) and the syllabification of liquids (section 5). The analysis of prefix-stem structures in section 6 allows us to place the rule of Initial Adjunction in the postcyclic component. It also permits us to establish that Initial Adjunction should be understood as linking to the phonological word rather than the syllable onset. We conclude that prefixes are class 2 postcyclic affixes. This explains their behaviour regarding syllabification and makes it clear why they do not interact with cyclic phonological rules. The most important conclusions are recapitulated in section 7.

\section{Basic Syllable Structure}

In this section we introduce background information by presenting the algorithm and the principles of syllabification for Polish. Our presentation is a brief summary of the results obtained by Rubach and Booij (1988) as they are relevant to the 'edge of constituent' question, which is the central topic of this article. 
The Syllable Structure Algorithm ${ }^{1}$ (SSA) consists of the following rules: ${ }^{2}$

\author{
SSA: N-placement \\ CV Rule \\ Polish Onset \\ Polish Coda \\ Complex Coda
}

Most of these rules are self-explanatory. As indicated below, the SSA starts applying in the cyclic component. We assume that there is a rule of Coda Erasure that makes it possible to reorganize syllable structure when new material is added in lexical derivation. N-placement and Syllabification rules assign syllable structure, which is entirely predictable in Polish. We assume with Levin (1985) that the syllable is characterized as a projection of the primitive category $\mathrm{N}$ (that is: nucleus). The node $\mathrm{N}^{\prime}$ denotes a rhyme and $\mathrm{N}^{\prime \prime}$ is the syllable node that may, but need not, contain an onset (hence the optional $X$ slot in the CV Rule below):

(2)

N-placement

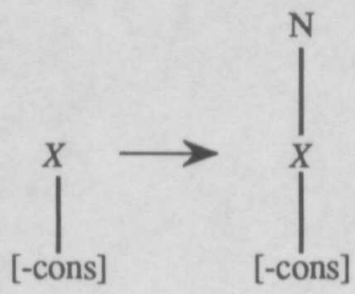

(3)

CV Rule

(X)

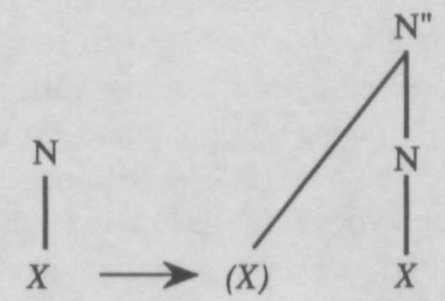

1 We assume the framework of three-dimensional phonology which crucially distinguishes between the melodic tier, the skeletal tier and the syllabic tier. See, for instance, Halle \& Vergnaud (1980), Steriade (1982) and Levin (1985).

${ }^{2}$ In Rubach \& Booij (1988) two further refinements of the Polish Syllable Structure Algorithm are postulated: High Vowel Constraint, which restricts the operation of N-placement, and Progressive Gliding. Their task is to derive glides from high vowels. We omit these considerations since they are not essential to the argumentation in this article. 
(4) Polish Onset

(5)

Polish Coda
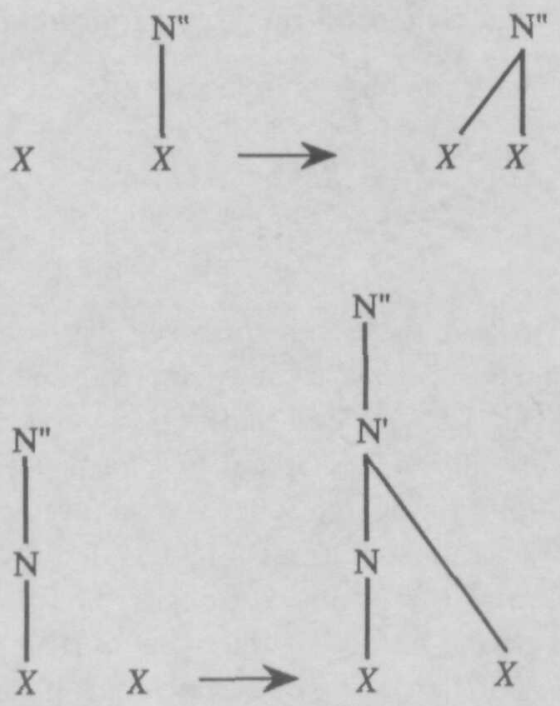

(6) Complex Coda
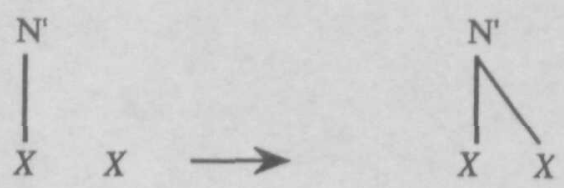

For descriptive convenience we shall omit the full hierarchical structure of the syllable and use the familiar $\sigma$ marking whenever reference to the details of syllabic structure is not essential. We assume that the syllables erected by the SSA are further gathered into phonological words that we call mots (Liberman and Prince's (1977) term).

The task of SSA is to organize skeletal $X$ slots into syllables. The SSA has access to the melodic tier since it is there that it can check that there is no violation of syllabification principles: the Sonority Sequencing Generalization (Selkirk 1984), ${ }^{3}$ which is universal, and the Obstruent Sequencing Principle, which is specific to Polish.

(7) Sonority Sequencing Generalization (SSG)

The sonority of segments must decrease towards the edges of the syllable in accordance with the following scale: vowelsliquids-nasals-fricatives-stops.

\footnotetext{
${ }^{3}$ See Clements (1988) for an interesting review of the evolution of the sonority hierarchy as a concept in phonology.
} 
The Obstruent Sequencing Principle places a condition on the operation of the SSG:

\section{Obstruent Sequencing Principle:}

With obstruents there is no requirement for sonority distance.

In effect (8) permits stops and fricatives in onsets and codas-to appear in either order. ${ }^{4}$ It is thus perfectly possible to have an onset that starts with a fricative and ends with a stop, for instance, pa-sta 'tooth paste', ka-ftan 'jacket'. However, geminates are always split between two syllables: las-so 'lasso', brut-to 'gross'. As pointed out to us by one of the reviewers, this behaviour of geminates need not be stipulated as a restriction on (8). It is probably universally true that intervocalic geminates are never syllabified together (cf. Kuryłowicz 1947).

It is essential for the structure of the argument in this article to demonstrate that, aside from (8), Polish indeed obeys the SSG. The evidence can be drawn from two types of source: native speaker judgments of permissible syllabifications, and the role that unsyllabified consonants play in phonological derivation. ${ }^{5}$

Native speaker judgments regarding syllabification were elicited using a test that was administered to a group of students at the University of Warsaw. The test contained a list of words of varying degrees of complexity. This was dictated to the students who were asked to write down the words, indicating syllable divisions by hyphens. The dictation proceeded very quickly, and no time for consideration was allowed. When the results were not clear, the dictation test was repeated with a larger group of students.

The test revealed that there is variation in dividing words into syllables. It also indicated that Polish shows a preference for the maximization of onsets. In (9) below we give the results for three words with consonant clusters of varied complexity. The figures denote the number of students who chose a particular syllable division. In the case of the VCCV pattern we checked also for intra-individual variation, that is, a group of 10 students took the syllabification test three times at intervals of at least a

\footnotetext{
${ }^{4}$ Dogil \& Luschützky (1988) assume that universally there is no sonority ordering among obstruents. Given this assumption, (8) is superfluous.

${ }^{5}$ Below we present a very succinct review of the relevant facts. For a more extensive treatment of this evidence, see Rubach \& Booij (1988).
} 
week. Three students syllabified the word differently upon repetition of the test. ${ }^{6}$

(9)a. Pattern VCCV: patrzeć [patšeć] 'look'

V-CCV pa-trzeć 36

VC-CV pat-rzeć 20

variation $3: 10$

b. Pattern VCCCV: listwa 'board'

VC-CCV lis-twa 40

VCC-CV list-wa 11

V-CCCV li-stwa 8

c. Pattern VCCCCV abstrakt 'abstract'

VC-CCCV ab-strakt 20

VCC-CCV abs-trakt 14

V-CCCCV a-bstrakt 6

The variation in (9) contrasts sharply with the results given in Table I below. These results indicate that the SSG operates in Polish. Both the range of variation and the maximization of onsets are subject to sonority restrictions in the sense that both are blocked if the parsing would result in a string not permitted by (7).

TABLE I

\begin{tabular}{lll}
\hline Example & Gloss & Number of instances \\
\hline kontakt & contact & kon-takt 45, ko-ntakt $\emptyset$ \\
kormoran & cormorant & kor-mo-ran 46, ko-rmo-ran 1 \\
partia [-tja] & party & par-tia 45, pa-rtia $\emptyset$ \\
konserwa & preserve & $\begin{array}{l}\text { kon-ser-wa 45, ko-nser-wa } \emptyset \\
\text { kon-se-rwa } \emptyset\end{array}$ \\
\hline
\end{tabular}

${ }^{6}$ In the following instances we diverge from the standard transcription symbols:

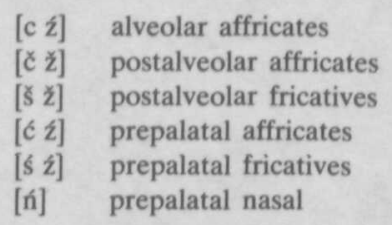

Note also that we use double slashes to denote underlying representations, single slashes for intermediate stages and the traditional square brackets for phonetic representation. 
The relevance of the SSG also comes to mind when we look at the role that it plays in the operation of phonological rules. Below we consider one example, (but see Bethin 1987 as well as Rubach \& Booij 1988).

The comparative degree is formed in Polish by adding the morpheme $s z / / \breve{s} / /$ to the adjectival stem. (The $s z$ is followed further by an inflectional ending):

$$
\begin{aligned}
& \text { słab }+\mathrm{y} \text { 'weak' } \quad-\text { słab }+\mathrm{sz}+\mathrm{y} \text { 'weaker' } \\
& \text { zdrow }+y \text { 'healthy' }- \text { zdrow }+s z+y \text { 'healthier' } \\
& \text { młod }+y \text { 'young' }- \text { młod }+\mathrm{sz}+\mathrm{y} \text { 'younger' } \\
& \text { star }+\mathrm{y} \text { 'old' } \quad-\text { star }+\mathrm{sz}+\mathrm{y} \text { 'older' }
\end{aligned}
$$

The consonant clusters that arise due to suffixation in (10) can easily be parsed by the SSA. The same is true if the adjectival stem ends in clusters of obstruents or a sonorant and an obstruent, as in (11a) below. However, the cluster of an obstruent followed by a sonorant triggers an allomorphy rule that inserts $e j$, as in (11b):

(11)a.

$$
\begin{array}{ll}
\text { prosty }+y \text { 'simple' } & \text { - prost }+\mathrm{sz}+\mathrm{y} \text { [prost }+\check{s}+\mathrm{i}] \\
\text { skąp }+\mathrm{y} \text { [skompi] 'mean' } & -\mathrm{skap}+\mathrm{sz}+\mathrm{y}[\text { skomp }+\check{\mathrm{s}}+\mathrm{i}] \\
\text { tward }+\mathrm{y} \text { 'hard' } & - \text { tward }+\mathrm{sz}+\mathrm{y}[\text { tfart }+\mathrm{s}+\mathrm{i}]
\end{array}
$$

b. szczupl + y 'slim'

$$
-\mathrm{szczupl}+\mathrm{ejsz}+\mathrm{y}[\mathrm{šc} u p l+\text { ejš }+\mathbf{i}]
$$

szczodr + y 'generous'

$$
- \text { szczodrz }+ \text { ejsz }+y[\text { [šcodž }+ \text { ejš }+i]
$$
ładn + y 'nice' $-\operatorname{ladn}+$ iejsz + y [ladń + ejš $+i]$

It has been observed independently by Bethin (1987) and by Rubach (1986a) that the appearance of the extended - ejs $z$ allomorph is conditioned by syllable structure. The /ej/ is inserted if the adjectival stem ends in an extrasyllabic consonant (the extrasyllabicity is marked by an asterisk):

$$
\text { Comparative Allomorphy } \emptyset \rightarrow \text { ej / C* }
$$
s..

The operation of Comparative Allomorphy ${ }^{7}$ is illustrated in (13). The $l$ of $s z c z u p l+e j s z+y$ 'slimmer' is identified as extrasyllabic and it triggers rule (12). Note also that the dark $l$ is palatalized to clear $l$ in the context of the front vowel. The relevant stage is cycle 2 :

\footnotetext{
7 The statement of Comparative Allomorphy has been simplified by leaving out reference to the skeletal tier. A fully formalized version given in Rubach \& Booij (1988) inserts:

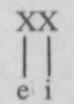

The $/ \mathrm{j} /$ is derived by Progressive Gliding. 
(13)

$$
\begin{array}{cl}
\begin{array}{cl}
\text { ščupl }+ \text { š } \\
1^{*}
\end{array} & \text { SSA } \\
\text { šcupł + ejš } & \text { Comparative Allomorphy } \\
\text { ščupl + ejš } & \text { Coronal Palatalization }
\end{array}
$$

This derivation demonstrates the relevance of the SSG, which does not permit the $l$ to be included into the coda. It also shows that the SSA starts applying in the cyclic component. This conclusion follows from the fact that the SSA provides crucial information for Comparative Allomorphy, which, rather unsurprisingly, is a cyclic rule. In general we would expect allomorphy rules to apply in the lexical (cyclic) component of the phonology. In the particular instance under analysis this general expectation is strengthened by the fact that Coronal Palatalization, which turns the dark $l$ into the clear $l$, is crucially cyclic (Rubach 1984). It applies in derived environments only (compare pletwa $+a$ 'fin' with szkol $+a$ 'school' $s z k o l+e$, locative singular). In the remainder of this article we shall assume that the SSA starts applying in the cyclic component and that it reapplies after every rule throughout the whole phonological derivation including the late postlexical stages.

To recapitulate briefly, the relevance of the SSG has been established on the basis of word-internal syllabification patterns and the operation of phonological rules.

Word-initial and word-final clusters highlight certain problems since it is there that violations of the SSG are not uncommon. Let us add that Polish, unlike Czech or Slovak, has no syllabic consonants.

(14)a. rwać 'tear', rdzeń 'marrow', rdza 'rust', lgnạć 'stick', łkać 'sob', łza 'tear', mdły 'tasteless', mżyć 'drizzle', mnich 'monk'.

b. Piotr 'Peter', bóbr 'beaver', metr 'meter', myśl 'thought' (N), cykl 'cycle', trefl 'clubs' (in cards), mechanizm 'mechanism', mielizn 'shallow' (genitive plural), pleśń 'mould', hymn 'anthem'.

These violations of the SSG should not lead to the conclusion that it does not operate in Polish. The following contrasts between word-initial and word-medial clusters in surface syllabification complete the evidence . that we have accumulated so far:

$$
\begin{aligned}
& \text { rtęć 'mercury' vs. kor-ty 'courts', never *ko-rty } \\
& \text { mścić 'average' vs. tłam-sić 'crush', never *tła-msić } \\
& \text { łkać 'sob' vs. pał-ka 'stick', never *pa-łka. }
\end{aligned}
$$

These violations of the SSG are found in word-initial and word-final 
clusters, that is, at edges of constituents. This is an important restriction that many researchers have observed. Word-initial and word-final segments have often been analyzed as appendices or extrametrical positions (Fudge 1969, Halle \& Vergnaud 1980, and Steriade 1982). These are also the positions where adjunction rules typically operate (Steriade 1982, Levin 1985). We believe that the apparent violations of the SSG in (14) should not be regarded as counterexamples. However, the offending segments do not delete by Stray Erasure (Steriade 1982), and hence they must be licensed prosodically (Itô 1986). In subsequent discussion we shall suggest that they are incorporated into prosodic structure by rules of adjunction, and not by any modified version of the SSA. The SSA remains unchanged and its operation is governed by the SSG.

Readers familiar with the structure of Slavic may wonder whether the violations of the SSG exemplified in (14) could not be explained by appealing to yers. We claim that such a move would not solve the problem, and we briefly clarify our stance in this matter below.

The term yer is used to refer to 'fleeting' vowels, that is, the vowels that alternate with zero. In the case of Polish the yers are instantiated primarily as the alternation between $e$ and $\emptyset$, for example sen 'dream' $s n+u$ (genitive singular). It was Lightner's discovery (1965, see Lightner 1972) that yers play a role in the contemporary phonology of Slavic languages. Laskowski (1975) was the first to document the importance of the yers for Polish (for a lexical interpretation of the yers, see Rubach 1984). The most recent analyses interpret yers in terms of the relation between the skeleton and the melody. Spencer (1986) suggests that yers are empty skeletal slots, whereas Kenstowicz \& Rubach (1987) as well as Rubach (1986a) regard them as floating matrices that are associated with a skeletal slot when they vocalize. The vocalization takes place before a yer (the circle around the vowel denotes a floating matrix):

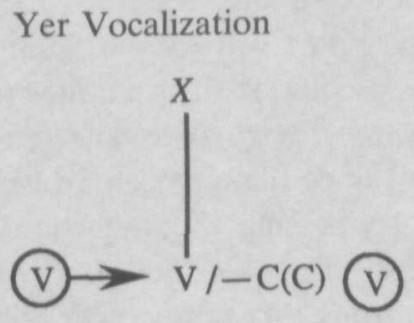

In accordance with the established generative tradition yers are assumed to occur not only in stems and derivational affixes but also in inflection. In the latter case they do not surface phonetically because they are never followed by a yer. Their presence is manifested indirectly, primarily as 
effects on other yers (vocalization) and in the distribution of palatalized and non-palatalized consonants (there are both front and back yers).

Let us look at the derivation of kladź, the imperative of klad $+q$ 'they put', and at the past tense forms sech $+l$ 'he dried' and $s c h+l+a$ 'she dried', where the imperative is a front yer and the masculine gender morpheme in the preterite is a back yer. The root sech has an underlying yer, as shown by the $e-\emptyset$ alternation in sech $+l$ 'he dried' and $s c h+l+a$ 'she dried'. The $-a$ is the feminine gender marker. Floating matrices are represented here as capital letters:

$$
\begin{aligned}
& \begin{array}{lllll}
\text { Cycle 2: } & \mathrm{klad}+\mathrm{E} & \mathrm{sEx}+1 & \mathrm{sEx}+1 & \\
& - & - & - & \text { Yer Vocalization }
\end{array} \\
& \text { kłaź + E - } \quad \text { _ } \quad \text { Coronal Palatalization }
\end{aligned}
$$

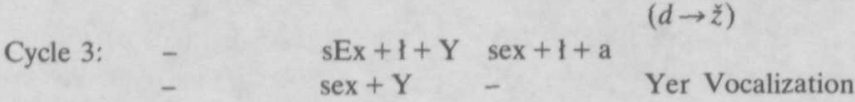

Unvocalized yers remain as floating matrices and they are ultimately subject to Stray Erasure (Steriade 1982).

Given the interpretation of Kenstowicz \& Rubach (1987) that yers are floating matrices, it is predicted that unvocalized yers cannot play any role in syllable structure: they carry no $X$-slots and hence are unavailable to the SSA. This prediction is borne out and indeed supported by both the operation of phonological rules and the facts of surface syllabification.

Recall that Comparative Allomorphy is cyclic and that it is sensitive to the presence of an extrasyllabic consonant. It applies at the stage where unvocalized yers are present (deletion of yers by rule or by Stray Erasure cannot be cyclic due to Structure Preservation and the Strict Cycle Constraint). Comparative Allomorphy ignores the yer and treats the final sonorant as unsyllabified. The relevant examples are found in the class of denominal adjectives. These are formed by adding the suffix //En//. Compare the $e=\emptyset$ alternation in win $+a$ 'guilt': win $+n+a$ 'guilty' (feminine) $=w i n+i e n$ [v'iń + en] 'guilty' (masculine). In a parallel form kwas

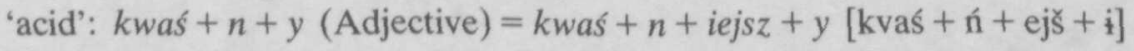
(comparative degree) the $e j$ is inserted since the unvocalized yer does not erect a syllable with $n$ as a coda. By-passing the inflectional ending, the underlying representation is $/ / \mathrm{kvas}+\mathrm{En}+\mathrm{s} / /$. The $n$ is perceived as extrasyllabic and Comparative Allomorphy takes effect: /kvaś + ń + ejš/.

All surface syllabification shows no trace of a yer playing a role in the division into syllables. Thus, oset 'thistle' ost $+y$ (plural), underlying //osEt// is syllabified exactly as most 'bridge' - most $+y$ (plural): $o-s t y$, mo-sty. Similarly, kuter 'cutter' (kutr $+a$ (genitive singular)) is syllabified 
like Piotr 'Peter' - Piotr $+a$ (genitive singular): ku-tra, Pio-tra. The last example brings us back to the problem highlighted by the violations of the SGG in (14).

Observe that Piotr 'Peter' cannot have an underlying yer before $r$. This is demonstrated not only by the fact that the yer would have surfaced as [e] before the nominative singular yer (as indeed it does in kuter 'cutter', see above). It is also indicated by another test: diminutive formation. The diminutive suffix has an underlying yer because of the $e-\emptyset$ alternation in e.g. $k o t+e k$ 'cat' (diminutive) $-k o t+k+a$ (genitive singular). Had there been a yer in Piotr, it would have necessarily vocalized under diminutivization. Yet, it does not: the diminutive form is Piotr $+e k$, and not *Pioter + ek.

Let us look at one further example. We have observed that the adjectivization morpheme is //En//. If myśl 'thought' (N) had a yer before the lateral, it would have surfaced not only in the nominative singular but also in the related adjective. Yet the nominative singular is myśl and the

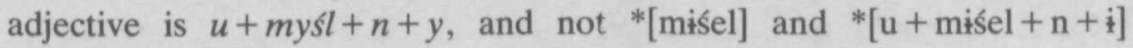
respectively.

In sum, there is positive evidence that the violations of the SSG are independent of the yers. They are found not only among clusters that include a yer such as rwać 'tear', but also among clusters without a yer such as Piotr 'Peter' and mysl 'thought'. Thus, unvocalized yers play no role in syllabification and therefore we will ignore them in the remainder of this article.

While most SSG violations occur at word edges, there is a small set of examples that exhibit unsyllabified consonants in word-medial position. These are cases where sonorants have been trapped between obstruents or in sonorant clusters that cannot be parsed by the SSA. ${ }^{8}$

In order to determine the facts, we return to the results of the test described above. For 19 students we measured intra-individual variation. These students took the same syllabification test three times at intervals of at least one week. In Table II we omit the syllabification of the irrelevant parts of the words. The variation figure $7: 19$ should be understood to mean that 7 out of 19 students gave different syllabifications of the word piosnka upon the repetition of the test.

\footnotetext{
${ }^{8}$ The relevant example is karmnik 'feeder' given in Table II. A. Gorecka (personal communication) has pointed out that sonorant clusters are not tolerated in the coda. This is a correct restriction for Polish. It is confirmed by the operation of Comparative Allomorphy

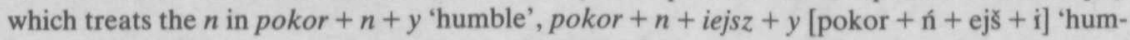
bler' as an unsyllabified segment. Notice that the SSG would not give this result since /-rn/ as a coda does not violate the SSG.
} 
TABLE II

\begin{tabular}{llll}
\hline Example & \multicolumn{2}{l}{ Number of Instances } & Variation \\
\hline piosnka & piosn-ka & 31 & $7: 19$ \\
'song' & pios-nka & 30 & \\
pierwiosnki & pierwiosn-ki & 34 & $9: 19$ \\
'primroses' & pierwios-nki & 26 & \\
karmnik & karm-nik & 46 & $7: 19$ \\
'feeder' & kar-mnik & 57 & \\
& & & \\
\hline
\end{tabular}

These results confirm rather than contradict the operation of the SSG. Evidently, the syllabifications piosn-ka and pios-nka are a matter of chance. Notice that in terms of pronunciation the $n$ must go with one of the syllables, because Polish has no syllabic consonants. The intriguing question is how to license the $n$ prosodically.

Two solutions come to mind. We could assume that the $n$ is optionally assigned to either the coda or the onset. ${ }^{9}$ Alternatively, we could assume that the $n$ is not a member of either syllable. Rather, it is linked directly to the node $m o t$, that is, the phonological word: ${ }^{10}$

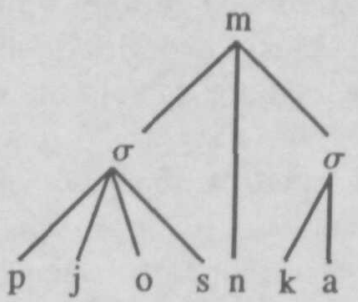

We shall discuss these alternatives in the following sections. For the moment let us merely observe that unsyllabified consonants are transparent to Voice Assimilation. In words such as Jędrk $+a$ [jentrk + a] 'Andy' (genitive singular) and $m e ̨ d r+c z+e[$ mentr $+\check{c}+\mathrm{e}]$ 'sage' (vocative singular) the $d$ is pronounced as [t]. Yet, underlyingly it is $d$ : compare Jędrek [-d-] (nominative singular) and mądr $+y[-\mathrm{d}-]$ 'wise'. Thus, there seems to be some relation between prosodic licensing and transparency to assimilation rules. We investigate these relations in sections 2 and 3 . We begin by considering Final Devoicing.

\footnotetext{
${ }^{9}$ We would like to thank one of the anonymous reviewers for drawing our attention to this possibility.

${ }^{10}$ The possibility of direct adjunction to the mot was suggested independently by Norval Smith in his work on non-Slavic languages (personal communication).
} 


\section{Final Devoicing}

We begin by briefly summarizing the analysis of Final Devoicing in Booij and Rubach (1987). In Polish, obstruents are devoiced at the end of a word: ${ }^{11}$

$$
\begin{gathered}
\text { sad +y 'orchard' (nom. pl.) sad [sat] (nom. sg.) } \\
\text { sad [sat] owocowy 'fruit tree } \\
\text { orchard' }
\end{gathered}
$$

versus

głod + ować 'to starve', głod $+\mathrm{n}+\mathrm{y}$ 'hungry': both have [d]

These data can be accounted for by either of the following rules ( $(20 \mathrm{a})$ is from Bethin 1984):

(20)a. Morphological Final Devoicing

$$
\text { [-son] } \rightarrow[\text {-voice }] /
$$

b. Prosodic Final Devoicing

$$
[\text {-son }] \rightarrow[\text {-voice }] /[]_{\text {mot }}
$$

That is, obstruents are devoiced at the end of the morphological word (20a) or the phonological word (20b). The selection of the correct version turns out to be a difficult task.

The behaviour of prepositions seems to throw some light on this problem. Prepositions do not undergo Final Devoicing if they stand in a proclitic position: pod [pod] owocem 'under the fruit', bez [bez] namyslu 'without thinking'. It appears that the blocking of Final Devoicing can be effected by resyllabifying the final obstruent of the preposition into the onset of the following word. If this solution were available, we would have an argument for (20b). However, Polish does not permit resyllabification across word boundaries. It is also impossible to assume that prepositions are simply exceptions to Final Devoicing, since they devoice in a nonproclitic position, for instance before a pause: pod [pot] 'under', bez [bez] 'without'.

Booij \& Rubach (1987) proposed that prepositions lose their status as separate words if they stand in a proclitic position. Although this analysis

11 The relevant contexts are that of a pause and that of a sonorant across word boundaries. If the following word begins with a voiced obstruent, then the word-final obstruent of the preceding word is later revoiced by Voice Assimilation (see section 3). Let us also note that we are referring to the dialects of central, northern and eastern Poland, the so-called Warsaw dialect. In the dialects of southern and western Poland, which are known as the Cracow dialect, obstruents are voiced before sonorants across word boundaries. 
is correct, it does not seem helpful in choosing between (20a) and (20b), since the rule responsible for the change of status of prepositions may have either of the two following formulations:

(21)a. Erase the bracket ] in a proclitic position:

[pod] [owocem] $\rightarrow$ [pod [owocem]]

b. Erase the node mot in a proclitic position

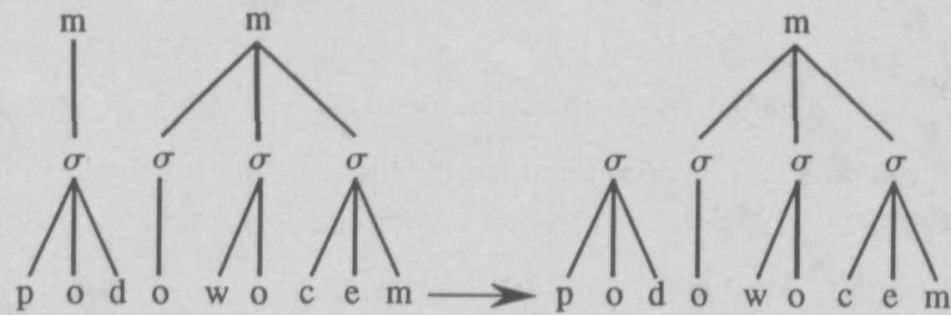

Both versions of restructuring in (21) render the correct result, but (21a) assumes that Final Devoicing is rule (20a) while (21b) presupposes that it is rule (20b).

The decisive evidence is rather marginal, and comes from the two nonsyllabic prepositions $w$ 'in' and $z$ 'with'. These are entirely parallel to pod 'under' and bez 'without' with one significant difference: they are not phonological words since they have no vowel and hence do not constitute a a syllable. Rule (20a) predicts that they should devoice before a pause, exactly like pod and bez. Rule (20b), prosodic Final Devoicing makes the opposite prediction: $w$ and $z$ are not phonological words, and hence they cannot devoice. This latter prediction is correct: $w$ and $z$ are pronounced [v] and [z] respectively before a pause. ${ }^{12}$ Booij and Rubach (1987) therefore concluded that $(20 \mathrm{~b})$ is the correct statement of the rule of Final Devoicing.

Let us now extend the set of data by considering words that end in a cluster of a voiced obstruent and a sonorant. Wierzchowska (1971) observes that the obstruent is then devoiced. ${ }^{13}$ This is in agreement with the observations made by one of the authors, Rubach, who is a native speaker of Polish. These observations have also been confirmed by recordings made with a group of students at the University of Warsaw. The students were asked to read fragments of texts where the relevant words appeared

\footnotetext{
${ }^{12}$ In the environment of a voiceless obstruent in the following word all prepositions devoice: pod [pot] parasolem 'under the umbrella', $w[\mathrm{f}]$ parasolu 'in the umbrella'. The devoicing is effected by Voice Assimilation that we discuss in section 3.

${ }^{13}$ The devoicing of obstruents may be suspended in slow and careful speech.
} 
before a pause (at the end of a sentence) or before a word beginning with a sonorant (a devoicing context, see (19) above). The voicelessness of the obstruent in word-final clusters must be due to a rule since we have alternations such as those in (22):

$$
\begin{aligned}
& \text { kadr + a [dr] 'staff' kadr [tr] (gen. pl.) } \\
& \text { pomodl + i + ć się [dl] 'pray' no to się pomódl [tl] 'so pray' } \\
& \text { (imp.) } \\
& \text { mielizn +y [zn] 'shallow' mielizn [sn] (gen. pl.) } \\
& \text { (nom. pl.) } \\
& \text { mechanizm }+y[\mathrm{zm}] \text { 'mech- mechanizm }[\mathrm{sm}](\text { nom. sg. })^{14} \\
& \text { anism' (nom. pl.) }
\end{aligned}
$$

Given Booij and Rubach's (1987) conclusion that Final Devoicing is a prosodically conditioned rule, i.e. (20b), nothing else needs to be said about these data: the obstruent is at the end of the phonological word since the word-final sonorant cannot be syllabified by the SSA:

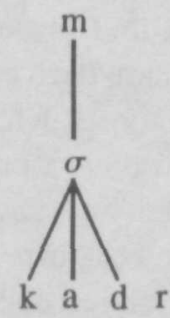

Thus, this analysis supports the claim that unsyllabified segments are invisible to prosodically conditioned rules. This is independently confirmed by the rule of Voice Assimilation to be discussed in section 3 .

The unprosodified sonorants in (22) must be licensed prosodically at some point since they are not stray erased. We therefore assume that Polish has an adjunction rule (cf. Steriade 1982 and Levin 1985 for this notion). The question then is to what constituent the extrasyllabic consonant is adjoined. It could be linked either to the coda or to the mot. Both types of adjunction would yield the correct results for (23).

Some light is thrown on this problem by the syllabification of words

\footnotetext{
${ }^{14}$ An interesting question is whether the final sonorant is voiced or voiceless. Wierzchowska (1971) states that the $m$ in spazm 'sobbing' is 'quite often" voiceless (p. 152), thereby implying that the devoicing may but does not have to take place. We concur. Rubach's observations show that there is a distinction between liquids and nasals: while liquids devoice, nasals may but do not have to. Thus, it is possible to have a voiced $m$ in mechanism [-sm] 'mechanism'. These observations extend also to the data that we adduce in (30) below.
} 
such as piosnka [p'josnka] 'song', discussed in section 1 (see Table II). In these words the word-medial sonorant goes either with the first or the second syllable. If adjunction were a rule of linking to the coda, the former, but not the latter possibility would be accounted for. An alternative view suggested in (18) in section 1 is to assume that the $n$ in piosnka is linked to the mot node. In that analysis, the variation in syllabification could be explained. When faced with the task of dividing this word into syllables, the subjects arbitrarily assigned the $n$ either to the preceding or to the following syllable. Notice that the adjunction rule must be obligatory since we cannot allow for some segment not to be adjoined. ${ }^{15}$ We therefore propose that extrasyllabic consonants can escape Stray Erasure since they are licensed prosodically by rule (24):

Housekeeping Adjunction: adjoin $\mathrm{C}^{*}$ to $m o t$

More evidence for this rule is provided in section 3 .

The question may now be asked at what stage in the derivation Housekeeping Adjunction has to apply. We know that it applies after Final Devoicing which in its turn applies after rule (21b) that erases the mot node in proclitic position. Since propositional phrases are derived syntactically, Final Devoicing must be a postlexical rule, and consequently Housekeeping Adjunction is also postlexical. This seems to pose a problem for words such as those in (22) when they are followed by a vowel-initial word, for example [mechanizm] [obronny] 'defence mechanism'. The fact is that $m$ remains syllabified with the first word, and, more generally, that Polish does not allow any resyllabification across word boundaries. That is, both the SSA and Housekeeping Adjunction are blocked. The reason for this behaviour of prosodic structure rules should be sought in the bracketing of constituents. We suggest that Polish is subject to the following constraint:

Prosodification Constraint:

Derivation of prosodic structure is blocked by the constituency bracket [.

This constraint is not only motivated by the data in (22), but also required for the analysis of prefix-stem structures in section 6 . Moreover, it is necessary in the derivation of compounds. Let us look at pas $+i+$

${ }^{15}$ This is an additional reason why words such as piosnka 'song' cannot be interpreted as being subject to either of the following hypothetical rules: (i) adjoin $\mathrm{C}^{*}$ to the coda, (ii) adjoin $\mathrm{C}^{*}$ to the onset. These rules would have to be optional since, as we have mentioned, the $n$ is pronounced either with the first or with the second syllable. 
brzuch $+y$ [pas $+\mathrm{i}+$ bžux $+\mathrm{i}]$ 'gluttons' which comes from pas $+a$ 'they feed' ( $-a$ is the third person plural ending) and brzuch 'belly'. The $i$ is the linking phoneme and the $-y$ is the nominative plural ending. There is no doubt that the morphological structure is that of (26):

$$
\left[\left[[\text { pas }]_{v^{i}}[\text { bžux }]_{N i}\right]_{N}\right.
$$

The linking phoneme $i$ joins the two parts of the compound and $\|\dot{i}\|$ is the ending for the entire compound, not only of its second constituent. However, from the prosodic point of view, the linking phoneme is part of the first constituent, and the inflectional ending belongs to the second constituent. This is shown by the following evidence:

(i) Syllabification: the syllabic structure is pa-si-brzu-chy.

(ii) Stress: the linking phoneme counts as part of the first constituent from the point of view of word stress, which is a penultimate stress rule. This is shown most clearly by compounds whose first constituent is polysyllabic, for example, norwésk $+o+p o ́ l s k+i$ Norwegian-Polish', where the Main Stress Rule operating in the domain of the mot assigns stress to each constituent independently. It is followed by the Compound Rule that makes the second constituent stronger (cf. Dogil 1979, see also Rubach and Booij 1985). (In the case of adjectives the linking phoneme is $o$.)

In summary, the prosodic structure of pas $+i+b r z u c h+y$ is as follows:

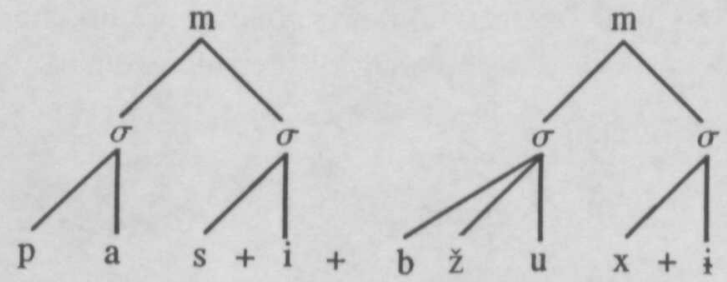

The Prosodification Constraint yields the correct result. The $\|\mathrm{i}\|$ is associated with the first, and the $\|\dot{i}\|$ with the second constituent since ] is transparent to prosodic integration while [ is not.

\section{Voice Assimilation}

In this section we look at another rule that makes reference to prosodic constituency and hence ignores extrasyllabic consonants. We discover an asymmetry in the treatment of word-medial and word-final unsyllabified segments on the one hand, and word-initial unsyllabified segments on the other hand. We begin with the presentation of the data. 
The following examples show that Polish has a regressive voice assimilation rule requiring that obstruent clusters agree in the value for voicing:

(28)a. ogrod + y [-d-] 'gardens'

ogród + k + i [-t-] (dimin., nom.pl.) ogród warzywny [-d v-] 'vegetable garden'

ogród kwiatowy [-t k-] 'flower garden'

$$
\text { grub }+y[-b-] \text { 'fat' } \quad \text { grub }+s z+y[-p+s \text { - }] \text { 'fatter' }
$$

pogrub długopisem [-b d-] 'make it thicker with a pen'

pogrub trochȩ [-p t-] 'make it slightly thicker'

b. kos $+\mathrm{i}+$ ć [-ś-] 'mow'

kos $+b+a[-z+b-]$ 'mowing' koś trawę [-s t-] 'mow the grass' koś żyto [-źž-] 'mow the rye'

$$
\text { kup }+\mathrm{i}+c[-\mathrm{p}-] \text { 'buy' } \begin{aligned}
& \text { kup }+\dot{\mathrm{z} e} \quad[-\mathrm{b}+\mathrm{z}-] \quad \text { 'do buy' } \\
& \text { (imper.), }
\end{aligned}
$$

kup farbȩ $[-p \mathrm{f}-]$ 'buy the paint' (imper.),

kup ziemniaki [-b ź-] 'buy the potatoes' (imper.)

Voice Assimilation applies in phrase phonology and hence is postlexical.

Given the hierarchical organization of phonetic feature nodes introduced by Clements (1985), the statement of the rule is eminently simple:

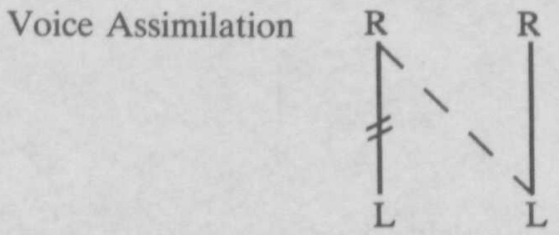

where R means 'root node' and L stands for 'laryngeal node'.

This way of formulating Voice Assimilation presuposes a theory of underspecification (cf. Kiparsky 1985) and, specifically, it makes the following assumptions:

(i) At the stage where the rule applies, all obstruents have been specified for voicing. That is, the Complement Rule [-son] $\rightarrow$ [-voice] has applied. Recall that the theory of underspecification claims that only voiced obstruents are marked for their voicing underlyingly. Voiceless obstruents are unspecified and they become voiceless by the Complement 
Rule. Like all other redundancy rules, the Complement Rule fills in blanks but cannot change values.

(ii) At the stage where Voice Assimilation applies all sonorants are still unspecified for voicing. That is, Sonorant Default [+sonor $] \rightarrow[+$ voice] has not applied yet. This explains why sonorants do not trigger Voice Assimilation but obstruents do.

(iii) The third assumption is Steriade's (1987) claim (taken up by Mascaró 1988) that the lack of specification for a given feature means the absence of the respective feature node in the hierarchical feature matrix. In the instance under consideration this means that sonorants have no $\mathrm{L}$ node at the stage where Voice Assimilation applies, that is, before Sonorant Default has taken effect.

Given these three assumptions we predict that liquids and nasals are transparent to Voice Assimilation. In other words, the rule applies as if the sonorants were not there. The prediction is borne out. Recordings made of students at the University of Warsaw support Rubach's observation that Voice Assimilation ignores intervening sonorants ${ }^{16}$ (see section 2 , and footnotes 11,14$)$ :

\section{(30)(a) Devoicing}

(i) mądr + y [-d-] 'clever' mȩdr $+\mathrm{k}+$ ować $[-\mathrm{tr}+\mathrm{k}-]$ 'to speak cleverly'

$$
\text { Jȩdrek [-d-] 'Andy' Jȩdr }+\mathrm{k}+\mathrm{a}[-\mathrm{tr}+\mathrm{k}-\mathrm{f} \text { (gen.sg.) }
$$

vs. jędr $+\mathrm{n}+\mathrm{y}$ 'firm': always [-d-] as there is no context for Voice Assimilation.

(ii) kadr fachowych [-tr f-] 'professional staffs' (gen.pl.) mechanizm przemian spolecznych [-sm p-] 'the mechanism of social changes'

mielizn przybrzeżnych [-sn p-] 'near shore shallow' (gen.pl.)

(b) Voicing

teatr wojenny [-dr v-] 'war theatre' wiatr zachodni [-dr z-] 'western wind' filtr wodny [-ldr v-] 'water filter' cykl wykładów [-gl v-] 'cycle of lectures' pomysl zawodów [-zw z-] 'the idea of the games'

\footnotetext{
16 In spelling or over-careful pronunciation the assimilation in (30) may be suspended. Note: in (30aii) the devoicing is effected by Final Devoicing, and Voice Assimilation is vacuous.
} 
czytelnia czasopism zagranicznych [-zm z-] 'international reading room

pieśń bojowa [-źń b-l 'war song'

Voice Assimilation applies before Sonorant Default. Consequently, sonorants have no $\mathrm{L}$ nodes and thus are transparent and cannot trigger assimilation. At a later stage Sonorant Default fills in the value [+voice], which is correct. However, this analysis is deficient in one important respect. While consonantal sonorants are indeed transparent to Voice Assimilation, vowels are not. The voicing distinction is always maintained in język 'tongue', mlod $+a$ par $+a$ 'bride and bridegroom', matow $+y$ 'unpolished', lat $+a$ wojn $+y$ 'war years'.

At this point either of the following two theories can capture the generalization that vowels are not transparent to Voice Assimilation:

Alternative 1:

There are two (not one) Sonorant Default rules: one for vowels and the other for consonants. Vowel Default applies before Voice Assimilation while Sonorant Default applies after Voice Assimilation. Then, vowels but not sonorant consonants are specified for voicing at the relevant stage; hence vowels have the blocking effect.

\section{Alternative 2:}

Voice Assimilation is a prosodically conditioned rule and it requires adjacency within a prosodic constituent.

The first alternative does not appear attractive as it would call for an otherwise unmotivated splitting of Sonorant Default into two rules. Also, Voice Assimilation would have to be restricted to the context of consonants in order to exclude the possibility that vowels could trigger the rule.

The second alternative seems simpler. We have one Sonorant Default. Adjacency of the input and the environment is established prosodically in a phonological phrase or an intonation group:

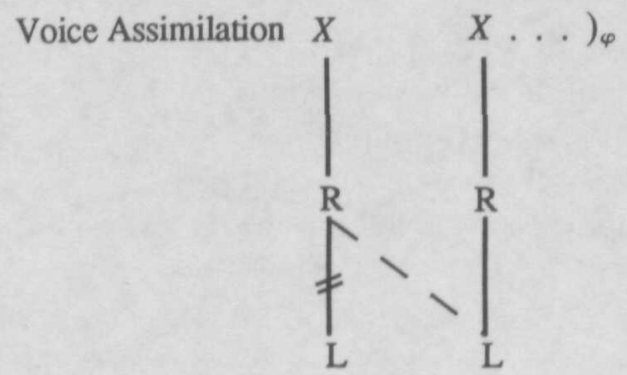


An intervening vowel breaks up the adjacency since vowels are always part of prosodic structure. Rule (31) makes the prediction that only unsyllabified consonsants can be transparent to voicing. This is a significant generalization that has passed unnoticed in earlier accounts of Polish (Mascaró 1988) and for closely parallel voicing facts in Russian (Kiparsky 1985).

The decisive evidence in favour of the prosodically oriented rule (31) comes from the consideration of the voicing effects in the presence of word-initial extrasyllabic consonants. The generalization is that these sonorants are not transparent to Voice Assimilation. ${ }^{17}$ The phrases below contrast with those in $(30 \mathrm{~b})$ in that the word-final obstruents remain voiceless:
brak rdzy [-k rz-] 'lack of rust' odglos rżenia [-s rž-] 'the sound of neighing' ryk lwa [-k lv-] 'roar of a lion' okres mdłości [-s md-] 'period of nausea' widok mżawki [-k mž-] 'the sight of drizzle'

Contrasts in devoicing can also be seen. Thus, the words in (30a) but not those in (33) below show the effect of Voice Assimilation:

$$
\begin{aligned}
& \text { pod [pod] mchem 'under the nose' } \\
& \text { bez [bez] mściwości 'without revenge' } \\
& \text { od [od] mszy 'since the mass' }
\end{aligned}
$$

Recall that proclitic prepositions do not undergo Final Devoicing (20b) since they have lost their mot node by rule (21). However, in principle there is no reason why they should not devoice by Voice Assimilation. Yet, they do not.

To summarize, word-initial extrasyllabic consonants are not transparent to Voice Assimilation. Consequently, they must be able to break up prosodic adjacency. We shall therefore assume that they have been adjoined prosodically before Voice Assimilation applies:

\section{Initial Adjunction: Adjoin word-initial $\mathrm{C}^{*}$ to mot.}

There are two queries that arise in connection with (34). First it is not clear why this should be an adjunction to the mot rather than to the

\footnotetext{
17 This is then different from the facts of Russian, as reported in Kiparsky (1985).
} 
syllable onset. To account for the facts of Voice Assimilation either of these adjunctions would yield the correct result. The second query is at what stage in the derivation Initial Adjunction should apply. More specifically, the question is whether initial Adjunction is postlexical or lexical. We postpone the discussion of these questions until section 6 .

Let us now illustrate how the phrases that undergo Voice Assimilation differ from those that do not. Our examples are teatr $[-d r]$ wojenny 'war theatre' and brak [-k] rdzy 'lack of rust':

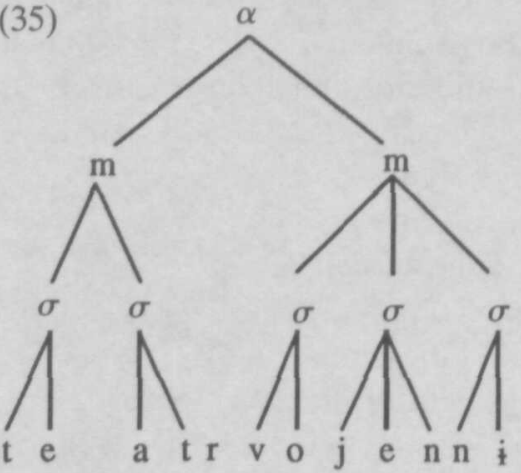

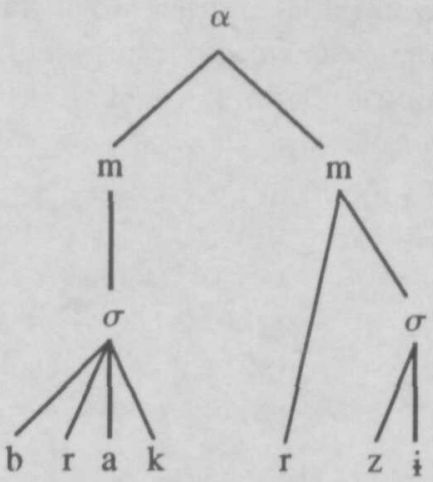

Marginally let us note a further interesting consequence of our analysis. We predict correctly that yers cannot block Voice Assimilation. Recall that unvocalized yers have no $X$ slots (see section 1) and hence are not prosodified. Thus, they cannot break up the adjacency of obstruents which is established at the level of prosodic constituency.

It is worthwhile pointing out that the contrasts exhibited in (30) and (32)-(33) cannot be accounted for by the theory of underspecification alone, without reference to prosodic constituency. The solution proposed by Kiparsky (1985) for Russian is not available for Polish. Kiparsky views Voice Assimilation as strictly local at the melodic tier. Thus, teatr wojenny 'war theatre' would be derived as in (36). (Note that capital letters denote segments unspecified for voicing.)

$\begin{array}{lll}\text { tEAtR } & \text { vOJENNI } & \\ \text { tEAtr } & \text { vOJENNI } & \text { Voice Assimilation } \\ \text { tEAdr } & \text { vOJENNI } & \text { Voice Assimilation } \\ \text { teadr } & \text { vojenni } & \text { Sonorant Default }\end{array}$

However, by the same token the $r$ in brak rdzy 'lack of rust' would voice in the context of $d z$ and then the $k$ of brak would become [g], which is incorrect. The facts of Polish are different from the facts of Russian.

In summary, the analysis of Voice Assimilation has confirmed our earlier observation that unsyllabified segments are not visible to rules that 
refer to prosodic constituency. This observation has been sharpened to the extent that segments adjoined to the mot block adjacency in prosodically conditioned assimilation rules. We have discovered an asymmetry in the behaviour of word-initial and non-word-initial extrasyllabic segments. The former are adjoined prior to Voice Assimilation, while the latter are licensed by Housekeeping Adjunction, a late postlexical rule.

In the next two sections we look at some other examples of the asymmetry between word-initial and non-word-initial unsyllabified segments. We return to Initial Adjunction in section 6.

\section{Degemination}

We begin by reviewing the basic facts. As shown in (37a), geminates are commonplace intervocalically. However, they are not permitted before or after a consonant: compare (37b), (37c), and (37d) respectively.

(37)a. flotyll + a 'fleet', wann + a 'bath-tub', win $+n+y$ 'guilty', lass +o 'lasso', pass + a 'spell', netto 'net'.

b. Sybill + a 'sibilla'

Sewill + a 'Sevilla'

Lozann + a 'Lausanne'

c. rosną $+c$ c [rosnoń + ć] 'grow'

pȩkną + ć [penknoń + ć]

'break'

piękn + o 'beauty'

przyjaźń 'friendship'

d. fontann + a 'fountain'

flotyll + a 'fleet'

pel $+1+a$ 'she weeded'

mirr + a 'myrrh'

less + ow + y 'loess' (Adj)

$$
\begin{aligned}
& \text { sybil + sk + i (Adj) } \\
& \text { sewil + sk + i (Adj) } \\
& \text { lozań + sk + i (Adj) } \\
& \text { rosn + as [rosn + ow̃] 'they } \\
& \text { grow' } \\
& \text { pȩkn + a [penkn + ow̃] } \\
& \text { 'they break' } \\
& \text { piękn + y 'beautiful' } \\
& \text { przyjazn + y' 'friendly' } \\
& \text { fontann [fontan] (gen. pl.) } \\
& \text { flotyll [flotil] (gen. pl.) } \\
& \text { peł + } 1 \text { [peł] 'he weeded' } \\
& \text { mirr [m'ir] (gen. pl.) } \\
& \text { less [les] 'loess' }
\end{aligned}
$$

\footnotetext{
${ }^{18}$ This and the preceding example are instances of adjectivization by adding the morpheme $-n$. At the underlying level $-n$ has two allomorphs; the palatalizing //En// as in glos 'voice' glos $+n+y$ 'loud' and the non-platalizing $/ / \mathrm{n} / /$ as in mięs $+o$ 'meet' - mięs $+n+y$ (Adj). We may assume that piękn $+y$ 'beautiful' and przyjazn $+y$ 'friendly' have the allomorph $/ / \mathrm{n} / /$. While this assumption seems preferable, it is not absolutely necessary. Assuming that the allomorph is $/ / \mathrm{En} / /$ would put piękn $+y$ through an additional stage of palatalization. The surface form would have been derived correctly anyway since Polish has a rule of Noncontinuant Depalatalization. This rule changes, amongst others, $/ \mathrm{n} /$ to [n] before $n$ (see Rubach 1984, p. 101). It is Noncontinuant Depalatalization that explains why we have the surface [nn] rather than [ńn] in kon 'horse', kon $+n+y$ (Adj).
} 
The degeminating words in $(37 \mathrm{~b}-\mathrm{d})$ require some explanation. At the underlying level almost all of them have yers (see section 1). These yers manifest themselves indirectly as palatalization in lozan $+s k+i$ 'Lausanne' (Adj) or directly as a surface [o] in rosn $+a$ [non] 'grow'. ${ }^{19}$

Unvocalized yers are ignored by Degemination and hence we shall not represent them here. The relevant representations in $(37 b-d)$ are then the following:

(38)i. /sibill + sk + i/ 'Sybilla' (Adj), /sevill + sk +i/ 'Sevilla' (Adj), /lozańn + sk + i/ 'Lausanne' (Adj)

ii. /fontann/ 'fountains' (gen.), /flotill/ 'fleets' (gen.), /pel $+1 /$ 'he weeded', /mirr/ 'myrrhs' (gen.), /less/ 'loess' (nom.) [the inflectional yers have been omitted]

iii. /rosnn +ow/ 'they grow', /penknn + ow/ 'they break', /pjenkn $+\mathrm{n}+\mathrm{i} /$ 'beautiful', /pšijazn $+\mathrm{n}+\mathbf{i} /$ 'friendly'

To handle these data the linear framework requires a mirror image rule as in (39):

Degemination<smiles>CCCCC(C)(C)C</smiles>

The statement of Degemination in (39) is inadequate in two respects. First, being a linear rule, (39) would incorrectly apply to word-internal geminates in (40a) below. Second, it would affect word-initial clusters in (40b). In both instances geminates surface phonetically:

(40)a. roz + złościć 'to anger', bez + zwłocznie 'immediately', od + drapać 'scrape off'

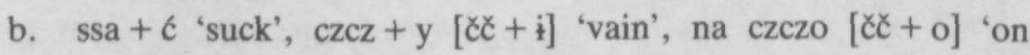
empty stomach', dżdżyst $+y$ [žž-] 'rainy', dżdżownic + a [žž-] 'earth-worm'

First let us address the problem posed by the data in (40a). The crucial question is how the words in (40a) differ from the degeminating words in (37b-d).

Observe that the determining factor for the degeminating words is the

19 The yer vocalizes to [o] in [non] not by Yer Vocalization but by Nasal Vowel Shift (Rubach 1984). 
presence of an unsyllabified consonant. At the relevant stage of derivation sybil $+s k+i$ 'Sibilla' (Adj), fontann 'fountain' (genitive plural) and rosn $+a$ 'they grow' have the following syllabic structure (we omit the yers):
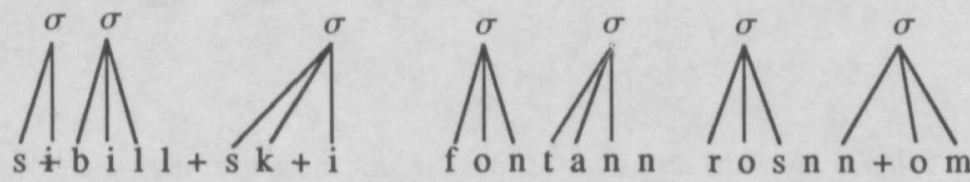

On the other hand, the words in (40a) are fully syllabified since no SSG violations occur. ${ }^{20}$

We conclude that Degemination is the prosodically oriented rule in (42):

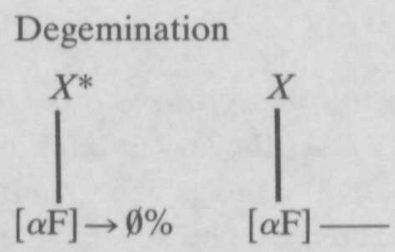

where the asterisk denotes an unlinked segment. ${ }^{21}$

Incidentally, the statement in (42) makes it clear that unvocalized yers cannot play any role in blocking Degemination: the rule refers to the skeleton and it is there that adjacency is established. Yers are floating matrices and they have no representation at the skeletal level.

Now we return to the data in $(40 \mathrm{~b})$. Notice that degemination applies word-finally but not word-initially, that is, we have the distinction between less [les] 'loess" and ssać [ssać] 'suck'. Notice also that Degemination applies word-medially: sybil $+s k+i$ 'Sybilla' (Adj). Given the results of Voice Assimilation in section 3, these observations are not surprising. They are an instance of the asymmetry between the word-initial and the non-word-initial positions. The unsyllabified word-initial consonants escape Degemination because Initial Adjunction has made them part of prosodic structure.

${ }^{20}$ We note one exception to our generalization. The word miękki /mjenkki/ undergoes Degemination, even though the SSA could parse it without leaving any unsyllabified material. We propose that the $k$ is either an exception to the Polish Coda Rule or that there is some language-specific constraint on its inclusion into the coda. Whichever the solution, the $k$ remains unsyllabified and deletes by Degemination.

${ }^{21}$ One may wonder whether the degeminating clusters should not be instances of multiply linked segments. The answer is negative: Polish violates the Obligatory Contour Principle. Thus, the dative singular of mirr $+a$ 'myrrh' is mirrz $+e$ [m'irž + e], see Rubach (1986b). 
(43)

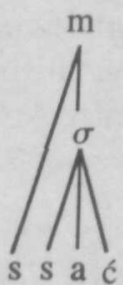

The analysis of Degemination demonstrates that instances of asymmetry are not restricted to assimilation rules such as Voice Assimilation. In the next section we look briefly at yet another type of situation. The facts are different but the asymmetry is the same.

\section{Excursus: Syllabic Liquids in Czech}

Michael Kenstowicz has drawn our attention to Trubetzkoy's (1939) statement that liquids are syllabic in Czech when "they occur after a consonant and are not followed by a vowel" (p. 172). This is confirmed by Petr et al. (1986, especially pp. 52, 144-45). Thus, we find syllabic liquids wordmedially in (44a) and word-finally in (44b) but not word-initially in (44c):

(44)a. srdce 'heart', zrno 'corn', plný 'full', vlna 'wool'

b. vichr 'wind', bobr 'beaver', bratr 'brother', bicykl 'bicycle', nesl 'he carried'

c. rty 'lips', rvát 'pull', rtut' 'mercury' lhát 'lie', lžíce 'spoon', Iněný 'linen' (Adj)

Clearly the rule that makes liquids syllabic obeys the same asymmetry that we have discovered in the case of Voice Assimilation and Degemination in Polish.

\section{PREFixes}

Now we return to Initial Adjunction. In particular, we look for the answer to the questions posed by the analysis of Voice Assimilation in section 3:

(i) Does Initial Adjunction link segments to the syllable onset or rather to the mot?

(ii) At which point in the grammar does Inital Adjunction apply?

We assume with Booij \& Rubach (1987) that there are three phonological 
components or strata: the cyclic (lexical) component, the postcyclic (lexical) component and the postlexical component. It is standard in Lexical Phonology to distinguish between the cyclic and the postlexical components. The added postcyclic component groups together the noncyclic word level rules.

The analysis of Voice Assimilation in section 3 throws little light on the problem of where to locate Initial Adjunction. We know that this rule precedes Voice Assimilation, but this latter rule is postlexical. Therefore, Initial Adjunction could also be postlexical. Below we will show that this assumption is false. It turns out that Initial Adjunction is postcyclic and that it links extrasyllabic segments to the node mot rather than to the syllable onset. These conclusions are based on the analysis of prefix-stem structures to which we turn now.

Prefixes show a number of peculiarities which differentiate them sharply from other affixes. Below we present their characteristic behaviour with respect to syllabification, phonotactics and phonological rules.

\section{A. Syllabification}

\section{CV Rule}

As might be expected, morphological structure has no influence on syllabification in Polish. Thus, the word but $+y$ 'shoes' is syllabified bu-ty, that is, the morpheme boundary is ignored. This, however, is not the case with prefixes, at least not in an overwhelming majority of cases. In Table III we present the results of the test that was conducted with students at the University of Warsaw (see the description of Table 1 in section 1 above). We syllabify the relevant portions of the word only. The number of instances varies since in the case of some words the test was repeated with several groups of students. The generalization is straightforward: the CV Rule is violated, that is, syllabification respects prefix junctures. Attention should be drawn to the last example in Table III. It contradicts the generalization just stated. However this is not surprising. The prefix juncture in rozumiec 'understand' is very difficult to motivate. It can be postulated only on the strength of the commutation test: rozumiec 'understand' vs. umieć 'know'. The semantic relationship between the two words can hardly be established. Evidently, we have a lexicalization of what used to be a morphologically transparent structure. Examples such as rozumieć indicate that prefix-stem words may be instances of varying degrees of lexicalization, which is also reflected in the facts of syllabification. Yet, the basic generalization holds: in transparent prefix-stem words the CV Rule is violated. 
TABLE III

\begin{tabular}{|c|c|c|c|c|}
\hline Example & Gloss & $\begin{array}{l}\text { Number } \\
\text { Instances }\end{array}$ & & Variation \\
\hline przed + egzaminacyjny & $\begin{array}{l}\text { pre-examination } \\
\text { (Adj) }\end{array}$ & $\begin{array}{l}\text { przed-e } \\
\text { prze-de }\end{array}$ & $\begin{array}{r}34 \\
1\end{array}$ & 0 \\
\hline bez + alkoholowy & alcohol-free & $\begin{array}{l}\text { bez-a } \\
\text { be-za }\end{array}$ & $\begin{array}{r}35 \\
0\end{array}$ & 0 \\
\hline roz + ognić & heat & $\begin{array}{l}\text { roz-o } \\
\text { ro-zo }\end{array}$ & $\begin{array}{r}40 \\
2\end{array}$ & 0 \\
\hline roz + iskrzyć & spark up & $\begin{array}{l}\text { roz-i } \\
\text { ro-zi }\end{array}$ & $\begin{array}{r}89 \\
4\end{array}$ & 0 \\
\hline nad + użyć & abuse & $\begin{array}{l}\text { nad-u } \\
\text { na-du }\end{array}$ & $\begin{array}{r}39 \\
6\end{array}$ & 1 \\
\hline roz + umieć & understand & $\begin{array}{l}\text { roz-u } \\
\text { ro-zu }\end{array}$ & $\begin{array}{r}2 \\
43\end{array}$ & 0 \\
\hline
\end{tabular}

\section{Sonority}

The examples in (45a) below show variation in syllabification while those in $(45 b)$ do not:

$$
\begin{aligned}
& \text { (45)(a) o +mdleć 'faint': o-mdleć om-dleć } \\
& \text { po +mścić 'avenge': po-mścić pom-ścić } \\
& \text { za + rdzewieć 'rust': za-rdze-wieć } \sim \text { zar-dze-wieć } \\
& \text { (b) pomp }+y \quad \text { 'pumps': pom-py } \\
& \text { zamsz + ow +y 'suede' (Adj): zam-szo-wy } \\
& \text { kobierc }+\mathrm{e} \quad \text { 'carpets': ko-bier-ce }
\end{aligned}
$$

The differences in syllabification between the nearly contrastive words in (45a) and (45b) can again be traced to the different morphological status: prefix juncture vs. no prefix juncture. Prefixed words form a special class in the sense that they seem to permit syllabifications in defiance of the Sonority Sequencing Generalization.

\section{B. Phonotactics}

Prefixed words exhibit an array of unusual phonotactic possibilities in the combinations of both consonants and vowels. The former are well illustrated in (45a). In the class of vowels the combinations that arise at prefix junctures are unusual in both quantity and quality. We thus find strings of vowels, as shown in (46): 


$$
\begin{array}{ll}
\text { za + okrąglić } & \text { 'round up', } \\
\text { po + otwierać } & \text { 'open up', } \\
\text { u + atrakcyjnić } & \text { 'make attractive', } \\
\text { u + ogólnić } & \text { 'make general', } \\
\text { po }+ \text { u }+ \text { ogólniać } & \text { 'generalize' (3 vowels) }
\end{array}
$$

The words in (46) contradict the generalization that vowel sequences are not allowed at morphological junctures in Polish. In the morpheme internal position vowel clusters are found only in borrowings, for example, poet $+a$ 'poet'.

Prefix junctures admit vowel combinations that are also unusual from the point of view of quality:

$$
\begin{array}{lll}
{[\mathrm{iV}]:} & w y+\text { obrazić } & \text { 'imagine' } \\
{[\mathrm{ii}]} & w y+\text { imaginować } & \text { 'imagine' } \\
{[\mathrm{Vu}]:} & \mathrm{za}+\text { ufać } & \text { 'trust' }
\end{array}
$$

In fact, the sequences in (47) normally occur only in syntactic phrases for instance, dobry obraz 'good picture'.

\section{Phonological Rules}

The exceptional nature of prefix - stem structures is also reflected in the operation of phonological rules. Thus, Polish has the well-known vowel deletion rule (Jakobson 1948): ${ }^{22}$

$$
\text { Vowel Deletion } \quad \mathrm{V} \rightarrow \emptyset /-\mathrm{V}]_{\text {Verb }}
$$

This rule is clearly violated by the data in (46) and (47).

The glide $/ \mathrm{j} /$ is deleted before consonants:

$$
j \text {-Deletion } \mathrm{j} \rightarrow \emptyset /-\mathrm{C}
$$

Thus, we have the following alternations in the forms of the Derived Imperfective of the stem ryw:

$$
\begin{array}{ll}
w y+r y w+a j & \text { 'pull out' (imper.) } \\
\text { vs. } & \\
w y+r y w+a+c & \text { 'to pull out' } \\
w y+r y w+a+1 & \text { 'he pulled out' } \\
w y+r y w+a+n+y & \text { 'pulled out' }
\end{array}
$$

\footnotetext{
${ }^{22}$ We have been reminded by one of the anonymous reviewers that Jakobson's rule was never intended to apply to prefixes, but only to verbal stems. Our intention is not to criticize Jakobson but rather to discover a way in which his generalization could be stated in terms of formal phonology. We propose below that prefixes are postcyclic while all other affixes are cyclic. Vowel Deletion is a cyclic rule.
} 
Rule (49) does not apply if a prefix juncture intervenes: naj + cichszy 'quietest', naj + ladniejszy 'most beautiful'.

Finally, we look at the vocalization of yers. Recall that yers are fleeting vowels that are represented as floating matrices (see section 1). They vocalize by rule (16): before another yer. Prefixes behave in a rather unusual way towards Yer Vocalization: the prefix yer vocalizes only in those instances where the stem yer has not vocalized (Rubach 1984, Booij $\&$ Rubach 1984). Let us return to the derivation of the words sech +1 'he dried' and $s c h+1+a$ 'she dried'. We subject these forms to prefixation: roz + sech $+l$ 'he dried out' and roze $+s c h+l+a$ 'she dried out'. We continue the derivation in (17) by looking at the prefix cycle (unvocalized yers are represented as capital letters):

$$
\begin{array}{cc}
\text { rozE }+\operatorname{sex}+1+Y & \operatorname{rozE}+s E x+1+a \\
- & \text { roze }+s E x+1+a \\
\hline \text { roz }+ \text { sex }+1 & \text { roze }+s x+1+a
\end{array}
$$

Yer Vocalization Stray Erasure

In summary: whether a prefix will vocalize or not can be determined only if we know whether the stem yer has vocalized. Prefixes must therefore be processed last, even after inflectional morphology. (The yer that conditions the vocalization of $/ / \mathrm{sEx} / /$ to $/ \mathrm{sex} /$ in the form on the left in (17) in section 1 is the masculine gender marker $Y$.) This leads to a paradox, since from the point of view of morphology, prefixes are added on earlier cycles than many derivational as well as all inflectional suffixes. Thus, pod $+d a+n+y$ 'subject' is derived from pod $+d a+c$ 'to subject' and not from $d a+n+y$ plus prefixation. Similarly, pod $+d a+n+s t w+o$ 'serfdom' comes from pod $+d a+n+y$ 'subject' and not from $d a+n+s t w+o$ plus prefixation.

In the preceding paragraphs we have enumerated a number of rather peculiar properties that distinguish prefixes from all other affixes in Polish. The natural question is how to express the special status of prefixes. In answering this we shall avail ourselves of the solution proposed by Halle (1987) for Yer Vocalization in Russian.

Countering the objections raised by critics of Lexical Phonology such as Aronoff \& Sridhar (1987) and Sproat (1985), Halle assumes that word formation rules and cyclic phonological rules do not apply in tandem. Rather, word formation is carried out first and then we apply phonological 
rules which operate cyclically in the cyclic component. ${ }^{23}$ Prefixes are class 2 affixes. This explains why they should be processed phonologically after suffixes, which are class 1 affixes. Yer Vocalization is a rule that applies both in the cyclic stratum 1 and in the noncyclic stratum 2 .

We can adopt Halle's solution for Polish without any modification since with respect to Yer Vocalization the facts of Russian and Polish are identical. At the beginning of this section we assumed with Booij \& Rubach (1987) that there are three phonological components: cyclic, postcyclic (both lexical) and postlexical. Prefixes are then postcyclic affixes. Yer Vocalization is one of those rules that apply in more than one component. More specifically, Yer Vocalization is both cyclic and postcyclic. Nothing more needs to be said. Yer Vocalization produces the corrrect output.

The peculiar properties of prefixes with regard to phonological rules and phonotactics are now accounted for in a straightforward fashion. All the phonological rules that we mentioned while discussing the prefixes are cyclic for independent reasons (see Rubach 1984). They do not interact with the prefixes precisely because the prefixes are postcyclic. The peculiar clustering of vowels across prefix boundaries is not unusual either since the postcyclic component is the stratum of word level phonology.

The facts of syllabification do not yield as readily to a similarly straightforward explanation, although many of them are automatically accounted for. For example, while patrzeć [patšeć] 'look' shows variation in syllabification, $z a+$ trzepotac $[\mathrm{za}+\mathrm{tše}$-] 'flap' normally does not, even though the segmental make-up of the relevant parts of these words is identical: pa-trzeć $\sim$ pat-rzeć (see (9a) in section 1) vs. za-trze-po-tać. This result is obtained precisely by assuming that prefixes are postcyclic. The stem trzepotać is syllabified in the cyclic component, hence the addition of the prefix $z a$ - in the postcyclic component has no effect on syllable structure.

Now we return to Table III given at the beginning of this section. The generalization is that the CV Rule is violated at prefix junctures. Thus, the prefix boundary in przed + egzaminacyjny 'pre-examination' (Adj) coincides with the syllable boundary. The difficulty in deriving the correct output is only apparent. Recall that in section 2 we postulated the Prosodification Constraint whose effect is to block the SSA by the bracket [.

\footnotetext{
23 This is the traditional view of the relation between morphology and phonology. It was adopted in the first half of Rubach (1984) for the analysis of the Polish data. The subsequent reinterpretation of the analysis in the second half of the book must now be abandoned. Given Halle's (1987) understanding of the status of prefixes, much of the argumentation for this reinterpretation disappears.
} 
The brackets are present in prefix-stem structures postcyclically since prefixes are postcyclic. That is, they have not been erased by Bracket Erasure at the end of the cyclic component. Thus, after postcyclic prefixation we have [przed[eqzaminacyjny]. The [ bracket blocks the CV Rule and the $d$ of przed-is picked up by the Coda Rule. The same procedure accounts for the syllabification of trans + oceaniczny 'transoceanic', where, predictably, the syllable boundary falls after trans-. This is a rather spectacular example since the prefix ends in a complex coda and yet there is no syllabification of the final prefix-consonant with the stem-initial syllable.

Finally, we return to the variation that was found at prefix boundaries in (45) earlier in this section. ${ }^{24}$ Recall that words such as $o+$ mdleć 'faint' show two possible syllabifications: $o-m$ dleć and $o m-$ dleć. We complete the data by adding some more examples. In Table IV we give the results of the test that was conducted with students at the University of Warsaw (see section 1). We syllabify the relevant portions of the word only. The last column denotes intra-individual variation that was discovered upon repetition of the same test with the same group of students. Recall that $6: 19$ means that 6 out of 19 students syllabified the same word differently in subsequent repetitions of the test.

Both types of syllabification exhibited by these examples seem to be problematic. Given our presentation so far we predict the following. In the postcyclic component $[o[$ mdlec $]]$ 'faint' and $[p o[$ rdzewiec $]]$ 'to rust' are syllabified as (o) ${ }_{\sigma} \mathrm{m}$ (dleć) $)_{\sigma}$ and (po $)_{\sigma} \mathrm{r}(\mathrm{ze})_{\sigma^{-}}$. that is, $m$ and $r$ are extrasyllabic. This syllabification is due to the fact that, on the one hand, the SSG has not permitted the sonorant to be included into the onset of mdlec and

TABLE IV

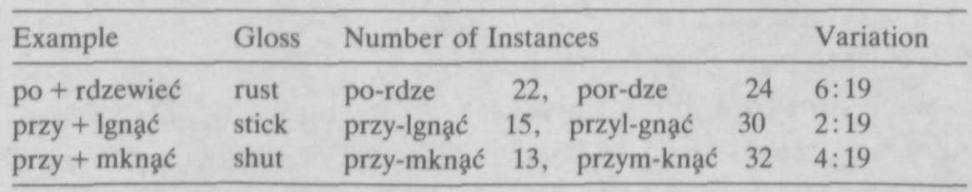

\footnotetext{
24 Variation in the assignment of the stem-initial consonant to the stem or to the prefix has also been found in some instances where the stem begins with a 'heavy' cluster. The 'heaviness' of the cluster seems to be determined either by the number of consonants that it contains, by a particularly cumbersome sequence of consonants or by a combination of these two factors. For example, we have found variation in $o+$ chrzcic 'baptize' and wy $+k p i c$ 'ridicule': o-chrzcic och-rzcic, wy-kpic $\sim$ wyk-pic. These examples indicate that in addition to general constraints such as the SSG some language specific constraints must also play a role. If we assume that, due to these restrictions, the stem-initial consonant is not syllabified by the SSA, then it will be linked to the mot by Initial Adjunction. The variation is thus accounted for (see the discussion below).
} 
rdzewiec in the cyclic component. On the other hand, the Prosodification Constraint has blocked the syllabification of the $m$ and the $r$ as the coda of the prefix when the prefixes are added in the postcyclic component. The blocking effect of the Prosodification Constraint is no longer available in the postlexical component since internal brackets are erased at the end of the stratum/component. Consequently, the $m$ and the $r$ of omdlec and pordzewieć are syllabified as the coda of the prefix syllable. We thus derive om-dleć and por-dzewieć as the only possible syllabifications. The variation given in (45) and in Table IV is not accounted for.

Fortunately, an alternative account of the variation facts is available. Let us assume, rather uncontroversially, that the prosodic node mot is erected in the cyclic component, perhaps by a general convention. In the later components of phonology syllables are merely linked to the mot.The linking is governed by the familiar Prosodification Constraint. We thus obtain the following structure of $o+m$ dlec 'faint':

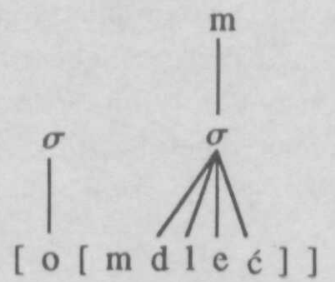

The Prosodification Constraint blocks the linking of the prefix syllable to the mot as well as the syllabification of the $m$ as a coda. The unsyllabified sonorant is picked up by Initial Adjunction (34) which derives the representation in (53):

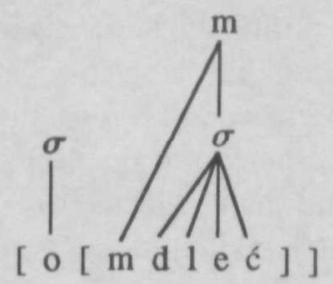

Postlexically, after Bracket Erasure at the end of the postcyclic component, the prefix syllable is linked to the mot:

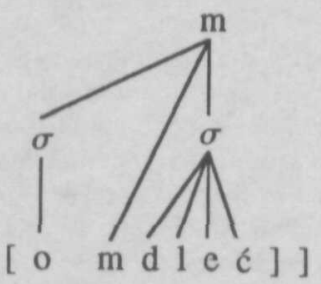


The sonorant $m$ has no status in any of the syllables. In terms of pronunciation the $m$ arbitrarily goes either with the first or with the second syllable. In this sense $o+$ mdleć is parallel to piosnka 'song' which we discussed in section 1 (see Table II). Both show the same type of variation in spite of the fact that in piosnka the nasal occurs between obstruents while in $o+$ mdleć it is flanked on the left side by a vowel. ${ }^{25}$

The analysis of words such as $o+m$ mleć provides the answer to the two questions that we posed at the beginning of this section: (i) whether Initial Adjunction involves linking to the mot or to the onset, and (ii) where in the structure of phonology Initial Adjunction should apply. The answer to the first question is that Initial Adjunction must link segments to the mot node. Had it linked segments to the onset, we would have derived $o$-mdleć as the only possible syllabification. That is, the variation $o$-mdleć $\sim$ om-dleć could not be accounted for.

The second question can also be answered. Initial Adjunction is a postcyclic rule. Had it been postlexical, it would have applied to the prefixstem structure without internal brackets since these brackets are erased at the end of the postcyclic component. Consequently, the Prosodification Constraint would not have been able to block syllabification of the $m$ as the coda of the prefix syllable in $o+$ mdleć. Thus, om-dleć would have been derived as the only possible structure. Again, the variation could not be accounted for.

The conclusion that Initial Adjunction is a postcyclic rather than a postlexical rule finds independent motivation in the analysis of Degemination that we presented in section 4 . Recall that sequences of identical consonants are simplified if one of them is extrasyllabic. Degemination cannot be cyclic since we are not able to determine whether it should take place until the whole morphological derivation has been completed. Thus, fontann $+a$ 'fountain' and pel $+l+a$ 'she weeded', which must escape Degemination, are /fotann/ and /pel $+1 /$ at the end of the first and second cycle respectively. We must wait until the last cycle in order to know whether Degemination should apply, that is, whether the relevant con-

${ }^{25}$ One of the reviewers asked what happens when the sonorant is trapped between obstruents in a word-initial cluster. There are some such cases, for example krtan 'larynx', grdyka 'Adam's apple'. One possibility is to assume that in this situation the sonorant is linked to the onset. This is a force majeure type of interpretation. The sonorant could not be linked to the mot since it would have to cross the association line for the initial consonant: the $k$ and the $g$ in our examples. The other possibility is to assume that the initial consonant (the $k$ in $k r t a n$ and the $g$ in $g r d y k a$ ) is not placed in the onset by the SSA and hence this consonant as well as the sonorant are adjoined to the mot by Initial Adjunction. In this way creating a cumbersome cluster in the onset would be avoided (see note 24). 
sonant will lose its extrasyllabicity due to the addition of a suffix on the next cycle.

The argument that Degemination cannot be postlexical comes from rule interaction. Briefly, Degemination must precede the so-called Nasal Gliding that turns $/ \mathrm{n} /$ to [ $]$ ] before a fricative. The point is that lozan + $s k+i$ [lozãj + sk' $+\mathrm{i}]$, the adjective from Lozanna 'Lausanne', undergoes Degemination at the stage where it has /ńń/. ${ }^{26}$ Nasal Gliding, which derives the phonetic [ j] in lozan $+s k+i$ is clearly a word level rule since it does not affect postlexical structures; for example, ston skacze 'the elephant is jumping' has [ń] and not [j]]. Initial Adjunction must precede Degemination. This is necessary because words such as ssac 'suck' must be able to escape Degemination (see section 4). We achieve the desirable result by assuming that Initial Adjunction has taken effect and, consequently, the first $s$ of $s s a c$ is prosodified (see (43)). We conclude that Initial Adjunction cannot be postlexical. Rather, it is postcyclic as it applies before postcyclic Degemination.

\section{Conclusion}

The analysis of edge of constituents effects has led to two signicfiant claims. First, prosodically conditioned rules treat unsyllabified segments as invisible. ${ }^{27}$ These segments are either transparent (Voice Assimilation) or they simply do not count (Final Devoicing). However, if an extrasyllabic segments has been licensed prosodically by adjunction, it becomes visible and has a blocking effect on prosodically conditioned rules (Voice Assimilation). Second, there is an asymmetry between the word-initial and the non-word-initial unsyllabified segments (Voice Assimilation, Degemination, Syllabic Liquids). This asymmetry is accounted for by postulating two rules: Initial Adjunction, which is postcyclic and Housekeeping Adjunction, which is postlexical.

Adjunction rules license segments prosodically and thereby make them immune to Stray Erasure. The facts of variation in syllabification suggest that prosodic licensing is effected by linking segments to the node mot, that is, the phonological word. The derivation of prosodic structure, in

\footnotetext{
${ }^{26}$ The cluster /ńń/ is the result of Nasal Palatal Assimilation (Rubach 1984). Note that the nasals should not be multiply linked.

${ }^{27}$ The restriction to prosodically conditioned rules is undoubtedly necessary. This is documented, among others, by palatalization rules. They are triggered by unvocalized yers that are floating matrices. Characteristically, these rules makes no reference to prosodic structure (Rubach 1984).
} 
particular, syllabification and linking to mot are governed by the Prosodification Constraint that treats the bracket [ as opaque.

\section{REFERENCES}

Aronoff, Mark and S. N. Sridhar: 1987, 'Morphological Levels in English and Kannada', in E. Gussmann (ed.) Rules and the Lexicon, Catholic University of Lublin, Lublin, pp. $10-22$.

Bethin, Christina Y :: 1984, 'Voicing Assimilation in Polish', International Journal of Slavic Linguistics and Poetics 29, 17-32.

- 1987, 'Syllable Structure and the Polish Imperative Desinence', Slavic and East European Journal 31, 76-89.

Booij, Geert E. and Jerzy Rubach: 1984, 'Morphological and Prosodic Domains in Lexical Phonology', Phonology Yearbook 1, 1-27.

- 1987, 'Postcyclic versus Postlexical Rules in Lexical Phonology', Linguistic Inquiry 18, 1-44.

Clements, George N.: 1985, 'The Geometry of Phonological Features', Phonology Yearbook 2, 225-252.

-: 1988, 'The Role of the Sonority Cycle in Core Syllabification', Cornell Papers in Laboratory Phonetics 2, 1-68.

Dogil, Grzegorz: 1979, Autosegmental Account of Phonological Emphasis, Linguistic Research Inc., Alberta.

Dogil, Grzegorz and Hans Ch. Luschützky: 1988, 'Notes on Sonority and Segmental Strength', to appear in Phonology.

Fudge, Eric C.: 1969, 'Syllables'. Journal of Linguistics 2. 253-287.

Halle, Morris: 1987, 'Why Phonological Strata Should not Include Affixation', unpublished manuscript, MIT.

Halle, Morris and Jean-Roger Vergnaud: 1980, 'Three-dimensional Phonology', Journal of Linguistic Research 1, 83-105.

Itô, Junko: 1986, Syllable Theory in Prosodic Phonology, unpublished Ph.D. dissertation, University of Massachusetts.

Jakobson, Roman: 1948, 'Russian Conjugation', Word 4, 155-167.

Kenstowicz, Michael and Jerzy Rubach: 1987, 'The Phonology of Syllabic Nuclei in Slovak', Language 63, 463-497.

Kiparsky, Paul: 1985, 'Some Consequences of Lexical Phonology', Phonology Yearbook 2, $85-138$.

Kuryłowicz, Jerzy: 1947, 'Contribution à la théorie de la syllabe', Biuletyn Polskiego Towarzystwa Językoznawczego 8, 80-113.

Laskowski, Roman: 1975, Studia nad morfonologị̣ wspólczesnego języka polskiego, Ossolineum, Wroclaw.

Levin, Juliette: 1985, A Metrical Theory of Syllabicity, unpublished Ph.D. dissertation, MIT.

Liberman, Mark and Alan Prince: 1977, 'On Stress and Linguistic Rhythm', Linguistic Inquiry 8, 249-336.

Lightner, Theodore M.: 1965, Segmental Phonology of Contemporary Standard Russian, unpublished Ph.D. dissertation, MIT.

: 1972, Problems in the Theory of Phonology, Vol. 1: Russian Phonology and Turkish Phonology. Linguistic Research Inc., Alberta.

Mascaró, Joan: 1988, 'A Reduction and Spreading Theory of Voicing and Other Effects', Linguistic Inquiry (in press).

Petr, J. et al.: 1986, Mluvnice češtiny Vol. 1, Academia, Praha.

Rubach, Jerzy: 1984, Cyclic and Lexical Phonology. The Structure of Polish, Foris Publications, Dordrecht. 
: 1986a, 'Abstract Vowels in Three-dimensional Phonology', The Linguistic Review 5, 247-280

-: 1986b, 'Does the Obligatory Principle Operate in Polish?', Studies in the Linguistic Sciences 16, 133-147.

Rubach, Jerzy and Geert E. Booij: 1985, 'A Grid Theory of Polish Stress', Lingua 66, 281-319.

: 1988, 'Syllable Structure Assignment in Polish', Vrije Universiteit Working Papers in in Linguistics 32, 1-59, to appear in Phonology 7. (1990).

Selkirk, Elizabeth O.: 1984, 'On the Major Class Features and Syllable Theory', in: M. Aronoff and R. Oehrle (eds.) Language Sound Structure, MIT Press, Cambridge Mass., 107-136.

Spencer, Andrew: 1986, 'A Non-Linear Analysis of Vowel-Zero Alterations in Polish', Journal of Linguistics 22, 249-280.

Sproat, Richard: 1985, On Deriving the Lexicon, unpublished Ph.D. dissertation, MIT.

Steriade, Donca: 1982, Greek Prosodies and the Nature of Syllabification, unpublished Ph.D. dissertation, MIT.

: 1987, 'Redundant Features', Papers from the Chicago Linguistic Society 23, part 2 (Parasession on Autosegmental and Metrical Phonology), 339-362.

Trubetzkoy, Nicolai S.: 1939, Principles of Phonology. Translated by C. A. M. Baltaxe, University of California Press, Berkeley and Los Angeles.

Wierzchowska, Bożena: 1971, Wymowa polska, Państwowe Zakłady Wydawnictw Szkolnych, Warszawa.

Received 29 November 1988

Revised 14 April 1989

(Rubach)

Instytut Anglistyki

Uniwersytet Warszawski

ul. Krakowskie Przedmieście 26/28

00-927 Warszawa

Poland

(Booij)

Vakgroep Taalkunde

Vrije Universiteit

P.O. Box 7161

1007 MC Amsterdam

The Netherlands 